\title{
Phylogenetic Diversity of the Cold Water Octocoral Paragorgia arborea (Linnaeus, 1758) off the East Coast of Canada
}

\author{
Kevin B. Strychar (Corresponding author) \\ Department of Life Sciences, Texas A \& M University - Corpus Christi \\ Corpus Christi, Texas, 78412, USA \\ Tel: 361-825-5883Ｅ-mail: kevin.strychar@tamucc.edu \\ Ellen L. Kenchington \& Lorraine C. Hamilton \\ Department of Fisheries and Oceans, Bedford Institute of Oceanography \\ Dartmouth, Nova Scotia, Canada
}

David B. Scott

Dalhousie University, Department of Earth Sciences, Halifax, Nova Scotia, Canada

\begin{abstract}
Commonly called "bubblegum coral', Paragorgia is a genus of cold-water gorgonian coral that has a broad global distribution and is eurybathic from depths of meters to kilometers. Such ecological breadth, however, may be confounded by the presence of cryptic species. In this study the genetic distances of various Paragorgia spp. across their distribution and depth range along the Canadian mid-Atlantic margin using $18 \mathrm{~S}$ ribosomal DNA sequences were compared. Morphometric and 18S evidence show that although appearing closely related, only one species of cold-water Paragorgia, called P. arborea, predominates in this region. However, $18 \mathrm{~S}$ evidence from corals collected at deep depths located at one site, called the Stone Fence, indicate that a significant amount of divergence exists and other species may also be present. Such new light provides a need for further genetic testing using alternative methods (e.g. microsatellites), which could reveal new lineages that may have considerable ecological and/or taxonomic importance.
\end{abstract}

Keywords: Cold-water coral, Deep-sea coral, Paragorgiidae, Paragorgia, 18S rDNA

\section{Introduction}

The gorgonian corals of the genus Paragorgia (Paragorgiidae; Octocorallia) are among the largest sessile benthic organisms commonly observed on continental shelves, seamounts, lithoherms, and canyons (Freiwald et al., 2004; Sanchez, 2005). Most species are fan-shaped and concave, with thick branches, reaching in excess of 2 $\mathrm{m}$ in height (Figure 1). Paragorgiids are unusual in that they lack a corneous or calcareous axial skeleton typical of most branching gorgonians (Sanchez, 2005). The massive structure is instead supported by calcitic sclerites, sometimes referred to as spicules (Bayer, 1993). They exhibit a wide color variation including red, salmon pink, white, black, brown, pumpkin orange and yellow (Diechmann, 1936). Descriptions of longevity vary from years (Koslow et al., 2001) to thousands (Rogers, 2004), which reflect varied growth conditions of each corals' specific habitat. In the northern Pacific regions Paragorgia sp. are reported to grow $2 \mathrm{~cm} \mathrm{yr}^{-1}$ which is ten times faster than the same species growing in the Atlantic (Andrews et al., 2002; Tsao, 2005); a two meter tall coral colony, then, is $\sim 112$ years of age. Based upon measurements of radioactive isotopes in the coral's skeleton, Mullineaux and Mills (2004) suggest that a $2 \mathrm{~m}$ tall Paragorgia specimen is at least 500 years of age. Because of their age and the complexity of their three-dimensional morphologies, Paragorgia and other deep-sea coral habitats may be analogous to condominiums hosting a plethora of bacteria (Penn et al., 2006) and micro- and macro-organisms (Buhl-Mortensen and Mortensen, 2004, 2005; Mortensen and Buhl-Mortensen, 2005; Nedashkovskaya et al., 2005). For example, Buhl-Mortensen and Mortensen (2005) identified 47 species (1,264 organisms) in thirteen Paragorgia colonies. Paragorgia sp. have also been identified as important fishery habitat for a variety of commercial fish, including Gadus macrocephalus (Pacific cod), Anoplopoma fimbria (sablefish), Pleurogrammus monopterygius (Atka mackerel), and Sebastes marinus (redfish) (Husebø et al., 2002; Auster et al., 2005; Heifetz et al., 2005). Due to the destructive practice of bottom trawling, many agencies worldwide are 
implementing marine protected areas (MPAs) in an attempt to delay any destruction they may experience and to allow scientists and opportunity to better describe the taxonomic status of Paragorgia and the commercial importance of this species (e.g. see Hall-Spencer et al., 2009; Gilkinson and Edinger, 2009).

Generally, Paragorgia spp. is believed to be eurybathic, with a global depth range between 18 and $5800 \mathrm{~m}$ (Tendal, 1992; Cairns and Bayer, 2009). They seem to prefer channels between submarine canyons, fishing banks, and deep ocean basins where strong unidirectional currents are present. We speculate that the resilience of such populations depends upon the supply of new recruits. Having been documented in the Aleutian Islands (Heifetz et al., 2005) and Seamounts in the Gulf of Alaska (T. Shirley, pers. comm.), Pacific Ocean (Nedashkovskaya et al., 2005; Baco, 2007), Atlantic and Indian Oceans (Bayer, 1964; Strychar et al., 2005), and in the Gulf of Mexico and Straits of Florida (NOAA, 2009), we hypothesize that these species have very high larval dispersal ability or exist as a result of suitable spacing of reef patches to allow for larval mixing (Vrijenhoek, 1997; Samadi et al., 2006; Morrison et al., 2008). Such populations are not likely self-seeded, as that would lead to long-term consequences and reduced chances of re-colonization (Morrison et al., 2008).

Using a variety of phenotypic traits (e.g. sclerites), Paragorgia spp. has been placed taxonomically within the Phylum Cnidaria, Class Anthozoa, Subclass Octocorallia, Order Gorgonacea, Suborder Scleraxonia, Family Paragorgiidae (Sanchez and Cairns, 2004). There may be as many as 19 characterized species of Paragorgia, however, controversy exists regarding their descriptive accuracy (Table 1). In the most recent revision of the genus, Sanchez (2005) suggests that only 14 Paragorgia species exist, and that Paragorgia nodosa and $P$. pacifica should be subsumed within $P$. arborea on the basis of the location of the siphonozooids, the autozooids having eight grooved notches associated with the aperture, and a common sclerite morphology. Previously, Verrill (1922) cast doubt as to whether P. pacifica is a valid species as the only diagnostic character was based on gross morphology. He felt that it too may be a variety of $P$. arborea. In accordance with Grasshoff (1979), Sanchez (2005) suggests that no phenotypic differences exist between $P$. boschmai and $P$. johnsoni, concluding that the taxonomic name "P. boschmai" is a junior synonymy of $P$. johnsoni. In addition, Bayer (1964) who examined sclerite morphologies of two Paragorgia species, indicates that $P$. dendroides is a junior synonymy of P. regalis. Paragorgia antilla, however, has not been reviewed since Bayer (1964), but is catalogued (numbers 56994, 50913) by the Smithsonian Institute.

Molecular studies have addressed the phylogenetic relationships of the cold water ahermatypic corals using $18 \mathrm{~S}$ rDNA (Berntson et al.,1999, 2001), 16S rRNA and large subunit rRNA (Sanchez et al., 2003), mitochondrial loci (Wirshing et al., 2005), rDNA (Waller et al., 2007), and inter-transcribed spacer region (ITS), 28S rDNA, and COI (Herrera et al., 2010). Using nuclear markers, Berntson et al. $(1999,2001)$ suggest that there are three major subclasses: (1) Octocorallia, (2) Hexacorallia, and (3) Ceriantipatharia. However, Bayer (1992) and Sanchez et al. $(2001,2003,2005)$ provide evidence that the Families Paragorgiidae and Coralliidae may not be monophyletic. Herrera et al. (2010) examined Paragorgia, the Coralliidae, and a group of undescribed specimens resembling Sibogagorgia and they suggest that their data support the monophyly of Paragorgia, Coralliidae, and Sibogagorgia. None of these studies, however, have specifically attempted to discern the interspecific morphological relationships within Paragorgia using molecular markers.

In previous studies, Strychar et al. (2005) have reported on the small-subunit 18S rDNA sequence variation from six species of Anthozoa, including Paragorgia sp. from the Canadian Atlantic, Pacific and the Bahamas. Initial results from that study showed high levels of sequence divergence between geographically distant Paragorgia taxa. Specimens of $P$. arborea from the Canadian Atlantic were very divergent from a Canadian Pacific specimen. In this paper, different levels of DNA sequence variation seen among 29 additional samples of Paragorgia taxa collected from three different localities and depths ranging from 186 to $630 \mathrm{~m}$ along Canada s eastern coast were studied. Data collected from this study and previously published sequences were used to independently test the current taxonomic status of the Paragorgia taxa.

\section{Materials and methods}

\subsection{Specimens}

Cold-water coral (CWC) were sequenced using a portion of the $18 \mathrm{~S}$ rDNA from 29 specimens of $P$. arborea collected from three different locations (Figure 2) which included the Northeast Channel (NEC; $\sim 42^{\circ} \mathrm{N}, 65^{\circ} \mathrm{W}$ ), the Gully ("G"; $\sim 43^{\circ} \mathrm{N}, 58^{\circ} \mathrm{W}$ ) and the Stone Fence (SF; $44^{\circ} \mathrm{N}, 56^{\circ} \mathrm{W}$ ); these specimens were collected at depths from 186 to $630 \mathrm{~m}$ (Table 2). All samples used were preserved in ethanol, however, samples provided by the Smithsonian Institute had been stored as dry specimens for periods ranging from 2 to 60 years and subsequently, were suspended in $90 \%$ ethanol. Fresh specimens used for this project were either collected from remote operated vehicles (ROVs) or fishing practices that include bottom dragging and/or long-line fishing. All 
specimens collected were frozen at $-20^{\circ} \mathrm{C}$ until subsampled into $90 \%$ ethanol. Sclerite morphology was examined in all 29 of the putative $P$. arborea specimens and showed the typical morphology of that species.

\subsection{DNA extraction and polymerase chain reaction (PCR) amplification protocol}

Phosphate buffered saline solution (PBS; Fisher Scientific, USA) was used to wash the sample and eliminate ethanol and surface contaminants. DNA was obtained by dissecting $100 \mathrm{mg}$ of tissue and extracting the DNA using a DNeasy tissue kit (Qiagen, Canada) according to the manufacturer's protocol.

A modified nested-PCR approach following Berntson et al. $(1999,2001)$ was used to amplify CWC 18 S rDNA. Two overlapping PCR products (primers A1 and B1; Table 3) were used to amplify the $18 \mathrm{~S}$ region of interest. Amplification consisted of 1 nmole of A1 or B1 primers and a corresponding internal oligonucleotide primer (primers A2-5, B2-5; Table 3), 200 nmoles of each dNTP, 1 unit of Taq DNA polymerase (MBI Fermentas, Canada), and $\sim 50$ to $100 \mathrm{ng}$ of DNA template, in a final volume of $50 \mu \mathrm{l}$. Specimens, including archival samples (i.e. from the Smithsonian Institute), that yielded no visible PCR product were amplified via a second PCR using 0.5 to $5 \mu \mathrm{l}$ from the initial PCR using universal eukaryotic coral primers A1 and B1. These samples were then purified and used as template for further reactions using our constructed internal primers (A2-A5, B2-B5; Table 3); $\sim 1 \mu$ of negative control from PCR methods that did not result in a visible product initially were used as template for a second negative PCR control. Thirty-nine cycles of PCR amplification using a MJ Dyad (MJ Research, USA) consisted of denaturation at $94^{\circ} \mathrm{C}$ for $60 \mathrm{~s}$, annealing at $57^{\circ} \mathrm{C}$ for $30 \mathrm{~s}$, and extension at $72^{\circ} \mathrm{C}$ for $60 \mathrm{~s}$, followed by one cycle with a $10 \mathrm{~min}$ extension at $72^{\circ} \mathrm{C}$. All PCR products were purified using a QIAquick PCR Purification (Qiagen) kit according to the manufacturer's protocol. To determine the molecular size and quality of the PCR products, all samples were run on $1 \%$ agarose gels and stained with ethidium bromide or SYBR safe (Invitrogen) and visualized on a Gene Genius (Syngene, UK).

\subsection{Sequencing of amplified $18 S$ rDNAs}

Eight to ten $18 \mathrm{~S}$ rDNA-specific primers were used in the sequencing reactions (Table 3). Approximately 40-80 ng of the PCR amplicons (quantity determined using PicoGreen ${ }^{\circ}$; Invitrogen-Molecular Probes, Canada) were sequenced using the BigDye Terminator Cycling Sequencing Ready Reaction Kit v 3.1 (Applied Biosystems, USA) following the manufacturer s recommendations. Sequencing reaction products were size fractionated on a BaseStation (MJ Research, USA) using 6\% acrylamide (FragPack, MJ Research, USA) and $20 \mathrm{~cm}$ plates or 5\% acrylamide (BasePack, MJ Research, USA) and $30 \mathrm{~cm}$ plates. The electropherograms were visualized using Cartographer software (MJ Research, USA).

\subsection{Phylogenetic analysis}

In addition to the 29 samples we collected for sequencing, three other Paragorgia samples from distant locations (e.g. the Bahamas - Paragorgia johnsoni), provided by the Smithsonian Institute, were also sequenced. Twelve additional sequences including out-groups were acquired from GenBank (Table 2).

Assembly and evolutionary analysis of the sequenced amplicons was done using GeneStudio Pro ${ }^{\circ}$. All sequences used in this project were compared against the sequences in the National Centre for Biotechnology Information (NCBI) GenBank site using the BLAST function in GeneStudio Pro ${ }^{\odot}$ and matching homologous $18 \mathrm{~S}$ rDNA sequences were retained for multiple alignment. A data set of 44 sequences with a length of 1,634 nucleotides (including indels) was assembled using aligned nucleotides with CLUSTAL W (Thompson et al., 1994) and Clustal X2 (Larkin et al., 2007). Using Mega 4.0.2 (Tamura et al., 2007), pair-wise sequence differences (p-distance) among sequences were computed, and phylogenetic trees using maximum likelihood (ML), minimum evolution (ME), and Bayesian likelihood analysis (BL) were constructed. Different tree-forming methods were used to reduce the likelihood of poor tree representation given the fact that each method is designed on the basis of different evolutionary theories and different algorithms (Steel and Penny, 2000). Maximum likelihood analysis was carried out using PAUP (Phylogenetic Analysis Using Parsimony, version 4.0b10; Swofford, 2002). In ML methods, a search for the topology that maximizes the chance of observing a given probabilistic model of nucleotide substitutions was used. Data sets comprised of more than seven sequences are computationally demanding and time-consuming and as a result, a quartet-puzzling algorithm (PHYLIP; Felsenstein, 1990) using the bootstrap function set to one million and a 50\% majority-rule consensus was used. A best-fit ME model using p-distance sequence divergence was performed using MEGA (Molecular Evolutionary Genetics Analysis V2.1). Minimum evolution analysis, unlike ML methods, assumes the shortest evolutionary route. One million bootstrap replications were used to test relative nodal support in the topology. Mr Bayes Version 3.0b4 (Huelsenbeck and Ronquist, 2001) was used for bayesian analysis utilizing the gamma function, "4-by-4" model, sampling one million generations, with Markov chains sampled every 100 iterations. The analysis was conducted three times using identical settings to ensure convergence on the same $1 \mathrm{n} L$ values 
(Huelsenbeck and Bollback, 2001). The number of random iterations generated prior to stationarity $(20,000$; called burn-in generations) were discarded and the subsequent generations used to establish the posterior probabilities. Bayesian trees using the software program BEAST 1.5.0 (Drummond and Rambaut, 2007) were also constructed for comparative analysis. In the program BEAST, we applied a relaxed clock uncorrelated lognorm, and the best-fit model of nucleotide substitution supported by the Akaike Information Criterion (AIC; Akaike, 1974) in jModeltest 0.1.1 (Posada, 2008). The MCMC chain length was set to 100 million generations with sampling every 1,000 links, and the first $10 \%$ of the dataset was discarded as burn-in. TreeView version 1.6.0 (Page, 1996) was used to display all phylogenetic trees. The out-group Beroe cucumis (Table 2) was used as previous studies have shown it to reliably root coral phylogenies (Berntson et al., 2001).

\section{Results}

\subsection{Northeast Channel}

All $P$. arborea specimens sequenced from this location were closely related as they appear to group together (Figures 3-5). In particular, samples N-1a,b (246 m, 249 m respectively) were very comparable (100\% nodal support; Figure 5) vs. N-1c (250 m), which appears to be more divergent and related to samples N-3b,c at depths $509 \mathrm{~m}$ and $542 \mathrm{~m}$, respectively (Figure 4 nodal support $=95 \%$ ). Two specimens from 262-380 $\mathrm{m}$ at this location also appear relatively comparable (N-2a,b; Figure 5 - nodal support $99 \%$ ) to samples obtained from deeper depths (e.g. N-3a, 100\% node support, Figure 5). In addition, at 262-456 m a mixture of samples from the Northeast Channel with specimens from shallower depths $(\sim 186 \mathrm{~m})$ from the Stone Fence and from distant locations (e.g. Bahamas and Bermuda; Figures 4,5) were observed.

\subsection{The Gully}

P. arborea from the Gully at shallow depths $(\mathrm{G}-1$ a-c; Figure 5 nodal support $=85 \%)$ appear related (convergent). As depth increased in the Gully, greater diversity of $P$. arborea mixing with specimens from other locations was observed. For example, two specimens (G-2a and G-2b; Figure 5) were related (nodal support = $74 \%$ ) at depths $472 \mathrm{~m}$. One sample (G-2c; Figure 5), however, was more comparable to species from the Northeast Channel and the Stone Fence (nodal support $=95 \%$; Figure 5). As depth increased ( $\geq 556 \mathrm{~m}$; Figure 5) each specimen sampled from the Atlantic appeared divergent: G-3a was more related to $P$. arborea from the Stone Fence (nodal support $=99 \%$; Figure 5), G-3 b was comparable to samples from the Pacific ( $99 \%$ nodal support; Figure 5), whilst G-3c appears closely related to species belonging to the Family Acanthogorgiidae (> $74 \%$ nodal support; Figures 3-5).

\subsection{Stone Fence}

Specimens of $P$. arborea sampled from the Stone Fence at shallow depths (186 m; S-1 a-c) from Atlantic Canada show the greatest diversity of species "mixing" with samples from various locations (e.g. Bermuda, Canadian-Pacific; Figure 5) and depths. At deeper depths (262-332 m), a high degree of divergence of S-2 a-c (Figures 3-5) was observed. One sample (S-2b; node support $>60 \%$; Figures 3, 5), however, was closely related to samples from the Gully, sample S-2a (node support $>70 \%$; Figures 3, 5) was more comparable to samples from the Northeast Channel, and S-2c (Figure 5) appeared closely associated with Anthomastus sp. (92\% nodal support; Figure 5) and P. arborea from the Gully (99\% nodal support; Figure 5). At deeper depths (>588-630 m) all three samples (S-3 a-c) were found to be closely associated with samples taken from shallower depths $(<472$ m) from the Gully (Figure 4).

\subsection{Generalizations}

Specimens of the geographically distant Paragorgia taxa show an interesting picture from the North Atlantic and Pacific compared to the Bermuda (denoted as Bahamas-1; Table 2) and Bahamas (labeled as Bahamas-2; Table 2) samples (see Figures 3-5). P. arborea from the North Pacific (British Columbia, Canada) are related to $P$. johnsoni from Bermuda (> 89\% nodal support; Figures 4, 5). P. arborea from the North Atlantic (Nova Scotia, Canada) however, appear divided. Specimens found in deeper waters, for example in the Gully (472-556 m; Figure 4) and the Stone Fence (262-630 m; Figure 4), appear more related to P. johnsoni from Bermuda (node support $=$ Figure $3-81 \%$; Figure $4 .-60 \%$; Figure $5-93 \%)$. In shallower waters $(<250 \mathrm{~m}), P$. arborea from Atlantic Canada collected from the Northeast Channel and the Stone Fence (Figure 3-99\%; Figure 4-86\%; Figure $5-100 \%$ ) were more closely related to the Bahamas specimen. The similarity of one sample of $P$. arborea (G-3c; Figures 3-5 and G-3b; Figure 4) relative to Chrysogorgia chryseis and Acanthorgorgia sp., both from Hawaii (100\% node support; Figure 5), and Siphonogorgia sp. from Palua (node support $=99 \%$; Figure 3 and 74\%; Figure 4) was unexpected. Similarily, the placement of Anthomastus sp. relative to these taxa was also unanticipated (Figures 3-5). Anthomastus sp. appears closely related to P. arborea from the Stone Fence at 
depths ranging from $262-332 \mathrm{~m}$ and the Gully at $\geq 556 \mathrm{~m}$ (nodal support $=75 \%$; Figure $3 ; 51 \%$; Figure 4 and 92\%; Figure).

Generally, samples from Atlantic Canada appear more related to each other (Figures 4, 5) compared to other anthozoans collected from various sites found globally (see Table 2). Base-pair differences observed on the 18S molecule were scattered and did not occur in a particular area or within loop structures. Maximum sequence divergence within Paragorgia sp. measured $0.428 \%$ overall taxa. Among the Paragorgia samples, there were minimal nucleotide differences (i.e. two to three base pair differences) with a consensus of 1.07 ( \pm 0.03 standard error) transition/transversion ratio. The greatest sequence divergence was between families considering they possessed the largest genetic distances and the lowest percent identities.

\section{Discussion}

Phylogenetic analyses of nuclear 18S rRNA show that specimens of $P$. arborea, using the ME (minimum evolution) and ML (maximum likelihood) methods, both produce two groups. One includes Paragorgia samples from Northeast Channel, Stone Fence, and Gully at all depths. The other includes Paragorgia samples from only the Stone Fence and Northeast Channel. In this group the Northeast Channel samples are from all depths but only the shallow group is included; in the ML tree, Bahamas-2 is added to this group. This would seem as if there are two "species" as other very distant taxa separate the samples. The BL (bayesian likelihood) method, however, gives a tree which is more consistent with current taxonomic concepts. The two groups are still maintained but they join together and include other Paragorgia taxa before linking with other genera (except for the Anthomastus sample). The division of Paragorgia samples into two different topologies are related to the treeing algorithms. Minimum evolution trees are estimated using the least-squares criterion in which a tree with the smallest sum of branch lengths with negative branch lengths, are disallowed. However, ML trees generally use all sequenced positions to determine branch lengths that have the highest probability of evolving a particular phylogeny (Felsenstein, 1981). In this study, more than seven sequences were used, hence, ML analyses would have been computationally demanding and time consuming and as a result, we used the quartet-puzzling algorithm. It is plausible that the $50 \%$ majority rule imposed relatively short evolutionary routes, which are consistent with ME analyses, and consequently produced comparable homologies.

The BL method is a much faster inference of phylogeny in which branch support is expressed as posterior probabilities, and when combined with bootstrap re-sampling procedures, Douady et al. (2003) suggests "very strong correlations" exists with traditional ML methods using bootstrapped maximum likelihood percentages. In this study, the BL method used was designed to be computationally demanding and analogous to the ML method, but without the time constraint. We believe this method produced the most robust phylogenetic model of evolutionary lineages that would be comparable to traditional computationally intensive ML analyses indicating two groups of Paragorgia exist, but shortly, in terms of evolution, two new species will likely result.

Upon examination of six CWC samples including three Paragorgia specimens from the North Pacific, Atlantic (Canada), and from Bermuda, Strychar et al. (2005) suggest that those samples from geographically different regions appear closely related. Attempts to explain why deep cold-water Paragorgia isolates from geographically different regions and depths appear closely related are hampered by a lack of knowledge of transmission of larvae from one region to another. It is possible that the isolation of distinct deep CWC genes here, and the classification of such corals into clades and subclades described by Berntson et al. $(2001,2002)$ is related to hydrography and circulation patterns along the Nova Scotian shelf (see Han et al., 1997; Townsend et al., 2004) and global ocean circulation patterns (Benzie, 1999). Along the Scotian Shelf (Figure 6), it becomes conceivable that recruitment of larvae may be transported between geographically different regions across the continental shelf (Davis et al., 1998) and possibly, circulation patterns of the Gulf Stream connect southern deep CWC species. The primary criticism of this hypothesis is that recruitment of Paragorgia larvae have not been described, even though gametes have been observed (pers. observ.). Further, contemporary currents shaping distribution patterns of species today are probably not operative as they were 100 years ago when samples used in this study, would have recruited.

There are 2000 known octocoral species, of which knowledge regarding their reproductive strategies (i.e. production of gametes and sperm) is only known in a few dozen. Asexual reproduction in these species occur via simple fission (Benayahu and Loya, 1985), partial mortality and separation of a colony (Farrant, 1985), survival and reattachment of fragmented colonies (Lasker, 1984), stolon and runner development from a parent colony (Dineson, 1985), fragmented colonial autotomy (Dahan and Benayahu, 1997) and parthenogenesis via planula development (Brazeau and Lasker, 1989). Two authors, Mullineaux and Mills (2004), suggested that reproduction of CWC is likely through budding via breakage and settling near a parent colony, indicating that 
many colonies of local distance are genetic clones. In addition, even though sexual reproduction of CWC has not been reported, oocytes have been observed in CWC bamboo corals (Family Isididae; pers. observ.). The presence of oocytes indicates the CWC may be broadcast spawners and/or brooders. Reports by Coma et al. (1995) suggest that brooding may be more common with CWC species. In other coral species, Coll et al. (1995) suggests that broadcast spawning is most common with Alcyonaceans and brooding occurs most commonly in gorgonian corals. Furthermore, vitellogenesis of mature oocytes in several unidentified species of bamboo corals exist, suggesting that larvae transportation via deep-water currents is possible.

Reproductive environmental cues are also well documented in shallow tropical corals and include, but are not limited to synchronized monthly gamete releases (Coma et al., 1995), lunar cycles (Kruger et al., 1998), water temperature (Dahan and Benayahu, 1997), tidal cycle (Alino and Coll, 1989), food delivery (Brito et al., 1997) and a variety of genetic factors. In the Family Paragorgiidae (order Alcyonacea) gonads have been observed in both autozooids and siphonozooids (Bayer, 1973) and although the time of release (spawning) remains unknown, we speculate that it coincides with nutrient upwelling and/or downwelling of increased production of particulate matter. Within temperate water, Lawson (1991) suggests that gorgonian-type alcyonaceans (e.g. Acanella arbuscula) have a seasonal reproductive cycle, evidenced by seasonal gametogenetic development. Hartnoll (1975) also suggests that seasonal gametogenesis in some octocorals is strongly correlated with periods of food availability. These authors observed gamete development in the temperate-water alcyonacean Alcyonium digitatum during early spring and summer plankton blooms. Similarly, Zeevi Ben-Yosef and Benayahu (1999) reported that reproduction of the Red Sea gorgonian Acabaria biserialis only occurs after a major seasonal phytoplankton bloom.

The placement of Anthomastus sp. relative to Paragorgia sp. was unexpected (Figures 3-5), however, Berntson et al. (2001) suggest that these taxa share many morphological features and are dimorphic. Furthermore, given that one sample of $P$. arborea from geographically distant regions and depths along the Scotian shelf (Canada) appeared related to Chrysogorgia chryseis and Acanthorgorgia sp., both from Hawaii (100\% node support; Figure 5), and Siphonogorgia sp. from Palua (node support $=99 \%$; Figure 3 and $74 \%$; Figure 4), we question the level of genetic similarity $(\mathrm{ME}=58 \%, \mathrm{ML}=<50 \%, \mathrm{BL}=64 \%$; Figures $3-5)$. We propose several possible reasons that may explain some of the disparities between the topology of these taxa. In this study we used octocoral specific designed primers for Paragorgia sp. which may not consistently amplify with the same efficiency across different taxa; this explanation would be true if failure to amplify consistently occurred, however, we observed PCR product and were able to sequence that product. Such biases inherent to natural mixes of rRNA genes are in the early stages of being investigated (see von Wintzingerode et al., 1997). Gene templates with high $\mathrm{G}+\mathrm{C}$ content, for example, are not as efficiently amplified as are those with low $\mathrm{G}+\mathrm{C}$ content (Reysenbach et al., 1992). Moon-van der Staay et al., (2000) also suggest that non-complementarity of either PCR primer may decrease PCR yield through inhibition of binding targets during high annealing temperatures. Further Hansen et al. (1998) suggest that some amplified sequences may be inhibited by DNA flanking the template region. The presence of excess templates during re-annealing may also reduce amplification of templates initially present in high abundance (Suzuki and Giovannoni, 1996). In contrast, Moon-van der Staay et al., (2000) suggest that templates with G/C content, when amplified with degenerated primers, amplify better than those with $\mathrm{A} / \mathrm{T}$ content. As a result primer specificity for some copies of the $18 \mathrm{~S}$ rDNA may be responsible for the unusual results of such phylogenetic analyses. Another explanation may be that the gene may not be divergent enough to use for intraspecific work. Even internal transcribed spacer regions may be too conserved for this type of work (Barth et al., 2006). Future studies should perhaps include the mitochondrial cytochrome $c$ oxidase (COI) gene since sequence discrimination amongst all animal phyla is reflected by the high rates of sequence change in this gene (COI) and intraspecific constraints on mitochondrial DNA divergence are due, in part, to interactions with the nuclear genome (Hebert et al., 2003). Lastly, PCR error rates may also account for some of the differences. Taq polymerase has the highest error rates of all known thermostable DNA polymerases (Ling et al., 1991). Further drawbacks associated with Taq polymerase are that the errors are biased towards $\mathrm{A} \bullet \mathrm{T} \rightarrow \mathrm{G} \cdot \mathrm{C}$ changes (Keohavong and Thilly, 1989) as was observed in this study; similar mutation bias has been reported by Kobayashi et al. (1998). In this study, the calculated error rate (5.7 $\times$ $10^{-5} /$ site / duplication) was computed using an equation given by Hayes $(1965 ; 2 \times$ observed error number / total length of DNA examined / effective number of duplications) and is consistent with reports by Flaman et al. (1994) and Cline et al. (1996). Kobayashi et al. (1999) suggest that the fidelity of PCR can be increased substantially by adding $P f u$ to $T a q$ during the PCR reaction.

\subsection{Northeast Channel}

In this study, some Paragorgia specimens from the Northeast Channel appear closely related, probably due to 
good mixing between surface and deep ocean waters. This is supported by Drinkwater et al. (1997) who reported that the strong tidal currents (as high as 3 to $5 \mathrm{~m}$ ) and formation of strong eddies, which last from a few days to over one year and extend as deep as $1000 \mathrm{~m}$, result in a nearly homogenous top to bottom water column regardless of season.

Paragorgia samples that appear related to the Stone Fence and from distant locations are likely the result of larval transport due to strong bottom ocean currents. Generally, circulation patterns along the Nova Scotian shelf appear to only flow along a southwest direction (i.e. flowing from the Stone Fence toward the Northeast Channel; Figure 5). A better perception of larval transport, and hence genetic diversity among geographically isolated populations, however, is to consider deep-ocean circulation patterns. Han et al. (1997) shows Gulf Stream ocean circulation patterns moving toward the North and Northwest. Such evidence implies that Paragorgia sp. mixing may occur from the Northeast Channel toward the Stone Fence, which lends support to observations in this study.

\subsection{The Gully}

The appearance of genetically comparable samples of Paragorgia at this location to other locations along the Scotian shelf is likely related to larval dispersal during summer months. Particle trajectories (Lacey, 2007a) indicate that $>65 \%$ of the water at the Gully travels Southwest toward the Northeast Channel. It is not surprising that some similarities exist between Paragorgia sp. at this location since $\sim 16 \%$ of the water forms eddies whilst $16 \%$ of the water travels west toward the shelf. In deeper water, similar trajectories are observed, however, $\sim 16 \%$ of the water travels northwest toward the Stone Fence as opposed to the Southwest as is observed in shallow water. We speculate that larval dispersal is unlikely to occur during the winter months since particle trajectories near the surface and in deeper water indicate that $~ 83 \%$ of the water eddies near the mouth of the Gully and/or travels toward the shelf with the remainder of the water mass eventually exiting and traveling Southwest toward the Northeast Channel; little or no water appears to travel from the Gully toward the Stone Fence during the winter season (Lacey, 2007b).

\subsection{Stone Fence}

Paragorgia sp. found at the Stone Fence are well clustered with other specimens at this location, from other locations along the Scotian Shelf, and amongst specimens found globally (i.e. Bermuda and the Bahamas). This result was not unexpected since the Stone Fence is a habitat found within a much larger inlet and river system called the Laurentian Channel (Figure 2). Further, seasonal water circulation patterns vary significantly to include tremendous mixing during the winter (Loder et al., 1993) via gyres and eddies, enormous amounts of water flushing/exchange (as much as $700,000 \mathrm{~m}^{3} / \mathrm{s}$; see Townsend et al., 2004) of the Channel during the spring to a predominately south-westerly flow of water out of the Channel. In addition, water that travels along the Scotian Shelf connects to the Gulf Stream (Figure 2) helping to promote further mixing between samples found in Canada with samples found amongst other, seemingly remote geographical locations (Davis et al., 1998).

\section{Conclusion}

Summarizing our data, this study demonstrates for the first time that Paragorgia sp. from eastern and western Canada, although appearing related in morphology, are genetically divergent. However, Sanchez (2005) suggests that two very comparable morphometric characteristics be used to subsume separate species (e.g. P. nodosa. and $P$. pacific into $P$. arborea) into one. This presumption is flawed since it is likely that these corals are displaying convergent evolution - that is, distantly related species evolving similar appearances due to comparable ecological niches. The evidence, then, suggests that molecular studies be used to address phylogenetic relationships between CWCs; even Verrill (1922) suggested that gross morphology is an inaccurate methodology for cryptic taxa. Further, other genera appear more closely related to Paragorgia then previously observed. The relatedness observed in this study is believed to be accurate since gene flow between organisms has been previously established in other coral studies (Ayre and Hughes, 2000; 2004) and over long distances (e.g. 4000 km, see Hellberg, 2004; and 500-1200 km, Fuchs et al., 2006). Hence, it is plausible that ocean currents are responsible for mixing and transmission of larvae thereby mediating gene flow between geographically separated species found along the Scotian Shelf. This new light potentially provides a novel assessment of the relative taxonomic distribution and abundance of the various groups of deep CWCs, associated fauna, and cryptic taxa and to their morphologies. It may also reveal additional lineages that may have considerable ecological and/or taxonomic importance.

\section{Acknowledgments}

We thank the Canadian Killam Trustees (Sir Izaak Walton Killam Memorial Fund), the Nova Scotia Museum 
(Canada), Texas Research Development Fund (US), and Texas A\&M University - Corpus Christi University Research Enhancement (US) who provided funding to Dr. K.B. Strychar. We also thank Dr. M. Risk who provided financial support. We acknowledge Dr. S. Cairns at the Smithsonian Institute and B. Hecker at Hecker Consulting for providing samples and technical advice. Special thanks to Dr. P. Mortensen for identifying samples and to Dr. Yongjiu Chen and M. Cavazos (TAMUCC) who reviewed, realigned, and statistically compared all phylogenies in this MS. Coral specimens from Atlantic Canada were collected through the Department of Fisheries and Oceans (DFO) at the Bedford Institute of Oceanography, Dartmouth, NS, Canada. We thank B. MacEachern, M. Showell and C. Bourbonnais-Boyce for preserving specimens collected during assessment surveys and through commercial fishing via observers.

\section{References}

Akaike, H. (1974). A new look at the statistical model identification. IEEE Transactions on Automatic Control, $19,716-723$.

Alino, P.M., \& Coll, J.C. (1989). Observations of the synchronized mass spawning and postsettlement activity of octocorals on the Great Barrier Reef, Australia: Biological Aspects. Bulletin of Marine Science, 45, 697-707.

Andrews, A.H., Cordes, E.E., Mahoney, M.M., Munk, J., Coale, K.H., Cailliet, G.M., \& Heifetz, J. (2002). Age, growth, and radiometric age validation of a deep-sea, habitat-forming gorgonian (Primnoa resedaeformis) from the Gulf of Alaska. Hydrobiology, 471, 101-110.

Auster, P.J., Moore, J., Heinonen, K.B., \& Watling, L. (2005). A habitat classification scheme for seamount landscapes: assessing the functional role of deep-water corals as fish habitat. In A.R. Freiwald, \& J.M. Roberts (Eds.), Cold-water Corals and Ecosystems (pp. 761-769). Springer-Verlag, Berlin Heidelberg.

Ayre, D.J., \& Hughes, T.P. (2000). Genotypic diversity and gene flow in brooding and spawning corals along the Great Barrier Reef, Australia. Evolution, 54, 1590-1605.

Ayre, D.J., \& Hughes, T.P. (2004). Climate change, genotypic diversity and gene flow in reef-building corals. Ecology Letters, 7, 273-278.

Baco, A.R. (2007). Explorationfor deep-sea corals on North Pacific Seamounts and Islands. Oceanography, 20, 108-117.

Barnett, T.P. (1988). Global sea level change: Climate variations over the past century and the greenhouse effect. First climate trends workshop. NOAA National Climate Program Office, Rockville, MD.

Barth, D., Krenek, S., Fokin, S.I., \& Berendonk, T.U. (2006). Intraspecific genetic variation in Paramecium revealed by mitochondrial cytochrome c oxidase I sequences. Journal of Eukaryotic Biology, 53, 20-25.

Bayer, F.M. (1964). A new species of the Octocorallian genus Paragorgia trawled in Florida waters by R.V. Gerda Zoologische Mededel (Leiden), 39, 526-532.

Bayer, F.M. (1973). Colonial organization in octocorals. In R.S. Boardman, A.H. Cheetham, \& W.A. Oliver (Eds.) Animal colonies: Development and function through time (pp. 69-93). Dowden, Hutchinson, and Ross, Inc., Stroudsberg, Pennsylvania.

Bayer, F.M. (1992). The Heloporacean Octocoral Ephiphaxum, recent and fossil: a monographic iconography. Studies in Tropical Oceanography, 15, 1-76.

Bayer, F.M. (1993). Two new species of the gorgonacean genus Paragorgia (Coelenterata: Octocorallia). Precious Corals and Octocoral Research, 2, 1-40.

Benzie, J.A.H. (1999). Genetic structure of coral reef organisms: ghosts of dispersal past. American Zoologist, 39, 131-145.

Berntson, E.A., France, S.C., \& Mullineaux, L.S. (1999). Phylogenetic relationships within the class Anthozoa (Phylum Cnidaria) based on nuclear 18S rDNA sequences. Molecular Phylogenetics and Evolution, 13, 417-433.

Berntson, E.A., Bayer, F.M., McArthur, A.G., \& France, S.C. (2001). Phylogenetic relationships within the Octocorallia (Cnidaria: Anthozoa) based on nuclear 18S rRNA sequences. Marine Biology, 138, 2 35-246.

Benayahu, Y., \& Loya, Y. (1985). Settlement and recruitment of a soft coral: Why is Xenia macrospiculata a successful colonizer? Bulletin of Marine Science, 36, 177-188.

Bluemle, J.P., Sabel, J.M., \& Karlén, W. (1999). Rate and magnitude of past global climate changes. Environmental GeoSciences, 6, 63-75. 
Brazeau, D.A., \& Lasker, H.R. (1989). The reproductive cycle and spawning in a Caribbean gorgonian. Biological Bulletin, 176, 1-7.

Brito, T.A.S., Tyler, P., \& Clarke, A. (1997). Reproductive biology of the Antarctic octocoral Thouarella variabilis Wright and Studer, 1889. In J.C. den Hartog (Ed.) Coelenterate Biology: Proceedings of the $6^{\text {th }}$ International Congress on Coelenterate Biology (pp. 63-69). National Natuurhistorisch Museum (Leiden).

Buhl-Mortensen, L., \& Mortensen, P.B. (2004). Crustaceans associated with the deep-water gorgonian corals Paragorgia arborea (L., 1758) and Primnoa resedaeformis (Gunn., 1763). Journal of Natural History, 38, 1233-1247.

Buhl-Mortensen, L., \& Mortensen, P.B. (2005). Distribution and diversity of species associated with deep-sea gorgonian corals off Atlantic Canada. In A.R. Freiwald, \& J.M. Roberts (Eds.) Cold-Water Corals and Ecosystems (pp. 849-879). Springer-Verlag, Berlin Heidelberg.

Cairns, S.D., \& Bayer, F.M.A. (2009). generic revision and phylogenetic analysis of the Primnoidae (Cnidaria: Octocorallia). Smithsonian Contributions to Zoology No. 629. Smithsonian Institution Scholarly Press, Washington, D.C.

Coll, J.C., Leone, P.A., Bowden, B.F., Carroll, A.R., Koenig, G.M., Heaton, A., Nys, R., Maida, M., \& Alino, P.M. (1995). Chemical aspects of mass spawning in corals. II. (-)-Epi-thunbergol, the sperm attractant in the eggs of the soft coral Lobophytum crassum (Cnidaria: Octocorallia). Maine Biology, 123, 137-143.

Coma, R., Zabala, M., \& Gili, J.M. (1995). Reproduction and cycle of gonadal development in the Mediterranean gorgonian Paramuricea clavata. Marine Ecology Progress Series, 117, 173-183.

Dahan, M., \& Benayahu, Y. (1997). Reproduction of Dendronephthya hemprichi (Cnidaria: Octocorallia): year-round spawning in an azooxanthellate soft coral. Marine Biology, 129, 573-579.

Davis, R.A., Thomson, D.H., \& Malme, C.I. (1998). Environmental assessment of seismic exploration on the Scotian Shelf. TA 2205. Report by LGL Ltd., King City, ON, for Mobil Oil Properties Ltd.,Shell Canada Ltd., Imperial Oil Ltd., and Canada/Nova Scotia Offshore Petroleum Board, Halifax, NS.

Deichmann, E. (1936). The Alcyonaria of the western part of the Atlantic Ocean. Memoirs of the Museum of Comparative Zoology (Harvard), 53, 1-317.

Dinesen, Z.D. (1985). Aspects of the life history of a stolon-bearing species Efflatonaria (Octocorallia: Xeniidae). Proceedings of the Fifth International Coral Reef Congress, 6, 89-94.

Douady, C.J., Delsuc, F., Boucher, Y., Doolittle, W.F., \& Douzery, E.J. (2003). Comparison of Bayesian and Maximum Likelihood bootstrap measures of phylogenetic reliability. Molecular Biology and Evolution, 20, 248-254.

Drinkwater, K.F., Pettipas, R.G., \& Petrie, W.M. (1997). Physical oceanographic conditions on the Scotian Shelf and in the Gulf of Maine during 1996. DFO Canadian Stock Assessment Research. Document. 97/62, 27 p.

Drummond, A.J., \& Rambaut, A. (2007). BEAST: Bayesian evolutionary analysis by sampling trees. BMC Evolutionary Biology, 7, 214.

Farrant, P.A. (1985). Reproduction in the temperate Australian soft coral Capnella gaboensis. Proceedings of the Fifth International Coral Reef Congress, 4, 319-324.

Felsenstein, J. (1981). Evolutionary trees from DNA sequences: a maximum likelihood approach. Journal of Molecular Evolution, 17, 368-376.

Felsenstein, J. (1990). Phylogeny Inference Package (PHYLIP), Version 3.6a2.1. University of Washington, Seattle.

Flaman, J.M., Frebourg, T., Moreau, V., Charbonnier, F., Martion, C., Ishioka, C., Friend, S.H., \& Iggo, R. (1994). A rapid PCR fidelity assay. Nucleic Acids Research, 22, 3259.

Freiwald, A., Fosså, J.H., Grehan, A., Koslow, T., \& Roberts, J.M. (2004). Cold-water Coral Reefs. UNEP-WCMC, Cambridge, UK.

Fuchs, Y., Douek, J., Rinkevich, B., \& Ben-Shlomo, R. (2006). Gene diversity and mode of reproduction in the brooded larvae of the coral Heteroxenia fuscescens. Journal of Heredity, 97, 493-498.

Gilkinson, K., \& Edinger, E. (2009). The ecology of deep-sea corals of Newfoundland and Labrador waters: biogeography, life history, biogeochemistry, and relation to fishes. Canadian Technical Report in Fisheries and Aquatic Sciences 2830, $136 \mathrm{p}$. 
Grasshoff, M. (1979). Zur bipolaren verbreitung der oktocoralle Paragorgia arborea (Cnidaria: Anthozoa: Scleraxonia). Senckenberg Marit, 11, 115-137.

Hall-Spencer, J.M., Tasker, M., Soffker, M., Christiansen, S., Rogers, S., Campbell, M., \& Hoydal, K. (2009). Design of marine protectedareason high seas and territorial waters of Rockall Bank. Marine Ecology Progress Series, 397, 305-308.

Han, G., Hannah, C.G., Loder, J.W., \& Smith, P.C. (1997). Seasonal variation of the three-dimensional mean circulation over the Scotian Shelf. Journal of Geophysical Research, 102, 1011-1025.

Hansen, M.C., Tolker-Nielsen, T., Givskov, M., \& Molin, S. (1998). Biased 16S rDNA PCR amplification caused by interference from DNA flanking the template region. Federation of European Microbiological Society - Microbial Ecology, 26, 141-149.

Hartnoll, R.G. (1975). The annual cycle of Alcyonium digitatum. Estuarine, Coastal and Shelf Science, 3, 71-78.

Hayes, W. (1965). The Genetics of Bacteria and Their Viruses. Wiley, New York.

Hebert PDN, Ratnasingham S, deWaard JR. (2003). Barcoding Animal Life: Cytochrome c Oxidase Subunit 1 Divergences among Closely Related Species. Biological Letters, 270, 96-99.

Heifetz, J., Wing, B.L., Stone, R.P., Malecha, P.W., \& Courtney, D.L. (2005). Corals of the Aleutian Islands. Fisheries Oceanography, 14, 131-138.

Herrera, S., Baco, A., \& Sánchez, J. (2010). Molecular systematic of the bubblegum coral genera (Paragorgiidae, Octocorallia) and description of a new deep-sea species. Molecular Phylogenetics and Evolution, 55, 123-135.

Hellberg, M.E. (1994). Relationships between inferred levels of gene flow and geographic distance in a philopatric coral, Balanophyllia elegans. Evolution, 48, 1829-1854.

Huelsenbeck, J.P., \& Bollback, J.P. (2001). Empirical and hierarchical Bayesian estimation of ancestral states. Systems Biology, 50, 351-366.

Huelsenbeck, J.P., \& Ronquist, R.R. (2001). Mr. Bayes: Bayesian inference of phylogenic trees. Bioinformatics, 17, 754-755.

Husebø, Å., Nøttestad, L., Fosså, J.H., Furevik, D.M., \& Jørgensen, S.B. (2002). Distribution and abundance of fhis in deep-sea coral habitats. Hydrobiologia, 471, 91-99.

Keohavong, P., \& Thilly, W.G. (1989). Fidelity of DNA polymerases in DNA amplification. Proceedings of the National Academy of Science, 86, 9253-9257.

Kobayashi, N., Tamura, K., Aotsuka, T., \& Katakura, H. (1998). Molecular phylogeny of twelve Asian species of epilachnine ladybird beetles (Coleoptera, Coccinellidae) with notes on the direction of host shifts. Zoological Science, 15, 47.

Kobayashi, N., Tamura, K., \& Aotsuka, T. (1999). PCR error and molecular population genetics. Biochemical Genetics, 37, 317-321.

Koslow, J.A., Gowlett-Holmes, K., Lowry, J.K., O'Hara, T., Poore, G.V.B., \& Williams, A. (2001). Seamount benthic macrofauna off southern Tasmania: Community structure and impacts of trawling. Marine Ecology Progress Series, 213, 111-125.

Kruger, A., Schleyer, M.H., \& Benayahu, Y. (1998). Reproduction in Anthelia glauca (Octocorallia: Xeniidae). I. Gametogenesis and larval brooding. Marine Biology, 131, 423-432.

Lacey, G. (2007a). Atlantic shelf circulation modeling - Gully in summer, drift trajectory. [Online] Available at http://www.mar.dfo-mpo.gc.ca/science/ocean/coastal_hydrodynamics/Circulation_Modelling/table_2/17d.html (accessed May 1, 2010).

Lacey, G. (2007b). Atlantic shelf circulation modeling - Gully in winter, drift trajectory. [Online] Available at http://www.mar.dfo-mpo.gc.ca/science/ocean/coastal_hydrodynamics/Circulation_Modelling/table_2/16d.html (accessed May 1, 2010).

Larkin, M.A., Blackshields, G., Brown, N.P., Chenna, R., McGettigan, P.A., McWilliam, H., Valentin, F., Wallace, I.M., Wilm, A., Lopez, R., Thompson, J.D., Gibson, T.J., \& Higgins, D.G. (2007). Clustal W and Clustal X version 2.0. Bioinformatics, 23, 2947-2948.

Loder, J.W., Drinkwater, K.F., Oakey, N.S., \& Horne, E.P.W. (1993). Circulation, hydrographic structure and mixing at tidal fronts: the view from Georges Bank. Royal Society of London Philosophical Transactions (A), 
$343,447-460$.

Lasker, H.R. (1984). Asexual reproduction, fragmentation, and skeletal morphology of a plexaurid gorgonian. Marine Ecology Progress Series, 19, 261-268.

Lawson, G.S. (1991). Preliminary evidence for seasonal reproduction in the deep-sea gorgonian Acanella arbuscula. Porcupine Newsletter 5, 29-35.

Ling, L.L., Keohavong, P., Dias, C., \& Thilly, W.G. (1991). Optimization of the polymerase chain reaction with regard to fidelity: Modified T7, Taq, and Vent polymerases. PCR Methods and Applications, 1, 63-69.

Moon-van der Staay, G.W.M., Guillou, L., Vaulot, D., Claustre, H., \& Medlin, L.K. (2000). Abundance and diversity of prymnesiophytes in the picoplankton community from the equatorial Pacific Ocean inferred from 18S rDNA sequences. Limnology and Oceanography, 45, 98-109.

Morrison, C.L., Johnson, R.L., King, T.L., Ross, S.W., \& Nizinski, M.S. (2008). Molecular assessment of deep-sea scleractinian coral biodiversity and population structure of Lophelia pertusa in the Gulf of Mexico. In K.J. Sulak (Ed.) Characterization of Northern Gulf of Mexico deepwater hard bottom communities with emphasison Lophelia coral - Lopheliareef megafaunal community structure, biotopes, genetics, microbial ecology, and geology (2004-2006) (pp. 4-78). USGS open file report 2008-1148; OCS study MMS 2008-015, Minerals Management Service, New Orleans, LA, USA.

Mortensen, P.B., \& Buhl-Mortensen, L. (2005). Morphology and growth of the deep-water gorgonians Primnoa resedaeformis and Paragorgia arborea. Marine Biology, 147, 775-788.

Mullineaux, L.S., \& Mills, S.W. (2004). Coral gardens in the dark depths. Ocean US Magazine 43, 22-27.

Nedashkovskaya, O.I., Kim, S.B., Lysenko, A.M., Frolova, G.M., Mikhailov, V.V., \& Bae, K.S. (2005). Bizionia paragorgiae gen. nov., sp. nov., a novel member of the family Flavobacteriaceae isolated from the soft coral Paragorgia arborea. International Journal of Systematic and Evolutionary Microbiology, 55, 375-378.

NOAA. (2009). Diversity of Octocorals. [Online] Available: http://oceanexplorer.noaa.gov/explorations /09lophelia/logs/aug28/aug28.html (August 28, 2009).

Page, R.D.M. (1996). TREEVIEW: an application to display phylogenetic trees on personal computers. Computer Applications in the Biosciences (Oxford), 12, 357-358.

Penn, K., Wu, D., Eisen, J.A., \& Ward, N. (2006). Characterization of bacterial communities associatedwith deep-sea corals on Gulf of Alaska Seamounts. Applied and Environmental Microbiology, 72, 1680-1683.

Posada, D. (2008). jModelTest: Phylogenetic Model Averaging. Molecular Biology and Evolution, 25, 1253-1256.

Rogers, A. (2004). The biology, ecology and vulnerability of deep-water coral reefs. The world conservation union (IUCN).

Reysenbach, A.L., Giver, L.J., Wickham, G.S., \& Pace, N.R. (1992). Limnology and Oceanography Differential amplification of rRNA genes by polymerase chain reaction. Applied Environmental Microbiology, 58, 3417-3418.

Sánchez, J.A. (2001). Systematics of the Southwestern Caribbean Muriceopsis Aurivillius (Cnidaria: Octocorallia: Gorgonacea) with description of a new species. Biological Society of Washington Bulletin, 10, $160-180$.

Sánchez, J.A., Lasker, H.R., \& Taylor, D.J. (2003). Phylogenetic analyses among octocorals (Cnidaria) according to mitochondrial and nuclear DNA sequences (1su-rRNA 16S, and ssu-rRNA 18S) support two convergent clades of branching gorgonians. Molecular Phylogenetics and Evolution, 29, 31-42.

Sánchez, J.A., \& Cairns, S.D. (2004). An unusual new gorgonian coral from the Aleutian Islands, North Pacific, Alaska. Zoologische Mededelingen, Leiden, 78, 265-274.

Sánchez, J.A. (2005). Systematics of the bubblegum corals (Cnidaria: Octocorallia: Paragorgiidae) with description of new species from New Zealand and the Eastern Pacific. Zootaxa, 1014, 1-72.

Steel, M., \& Penny, D. (2000). Parsimony, likelihood and the role of models in molecular phylogenetics. Molecular Biology and Evolution, 17, 839-850.

Strychar, K.B., Hamilton, L.C., Kenchington, E.L., \& Scott, D.B. (2005). Genetic circumscription of deep-water coral species in Canada using 18S rRNA. In A. Freiwald, \& J.M. Roberts (Eds.). Cold-water Corals and Ecosystems (pp. 679-690). Springer-Verlag Berlin Heidelberg. 
Suzuki, M.T., \& Giovannoni, S.J. (1996). Bias caused by template annealing in the amplification of mixtures of 16S rRNA genes by PCR. Applied Environmental Microbiology, 62, 625-630.

Swofford, D.L. (2002). PAUP*. Phylogenetic Analysis Using Parsimony (* and other methods). Version 4.0b10. Sinauer Associates, Sunderland, MA.

Tamura, K., Dudley, J., Nei, M., \& Kumar. S. (2007). MEGA4: Molecular Evolutionary Genetics Analysis (MEGA) software version 4.0. Molecular Biology and Evolution, 24, 1596-1599

Tendal, O.S. (1992). The North Atlantic distribution of the octocroal Paragorgia arborea (L., 1758) (Cnidaria: Anthozoa). Sarsia, 77, 213-217.

Thompson, J.D., Higgins, D.G., \& Gibson, T.J. (1994). CLUSTALW: Improving the sensitivity of progressive multiple sequence alignment through sequence weighting, position specific gap penalties and weight matrix choice. Nucleic Acids Research, 22, 4673-4680.

Townsend, D.W., Thomas, A.C., Mayer, L.M., \& Thomas, M.A. (2004). Oceanography of the Northwest Atlantic continental shelf. In A.R. Robinson, \& K.H. Brink (Eds.). The Sea: The global coastal Ocean Interdisciplinary regional Studies and Syntheses (pp. 1-57). Harvard University Press.

Tsao, F. (2005). Deep-sea corals are long-lived historians. Journal of Marine Education, 21, 22-23.

Verrill, A.E. (1922). The Alcyonaria of the Canadian Arctic Expedition, 1913-1918, with a Revision of some other Canadian genera and species. Report of the Canadian Arctic Expedition 1913-18 Vol VIII: Molluscs, Echinoderms, Coelenterates, Etc. Part G: Alcyonaria and Actinaria.

Vrijenhoek, R.C. (1997). Gene flow and genetic diversity in naturally fragmented metapopulations of deep-sea hydrothermal vent animals. The Journal of Heredity, 88, 285-293.

Waller, R.G., Adkins, J.F., Robinson, L.F., \& Shank, T.M. (2007). Ancient DNA techniques: Applications for deep-water corals. Bulletin of Marine Science, 81, 351-360.

Wirshing, H.H., Messing, C.G., Douady, C.J., Reed, J., Stanhope, M.J., \& Shivji, M.S. (2005). Phylogenetic relationships in the gorgonian family Plexauridae (Antozoa: Octocorallia: Holaxonia) based on two mitochondrial genes: Evidences for multiple lineages. Marine Biology, 147, 497-508.

Won, J.H., Rho, B.J., \& Song, J.L. (2001). A phylogenetic study of the Anthozoa (Phylum Cnidaria) based on morphological and molecular characters. Coral Reefs, 20, 39-50.

Zeevi Ben-Yosef, D., \& Benayahu, Y. (1999). The gorgonian coral Acabaria biserialis: life history of a successful colonizer of artificial substrata. Marine Biology, 135, 473-481. 
Table 1. Summary of morphological characters and the depth and locations of 19 Paragorgia species. Characters are defined as branch width, coral (coenenchyme) color, type and size of sclerites, and presence or absence of autozoids. Condition / Position are the descriptive trait(s) associated with each character. Differences in character types (e.g. size) are numbered, and are subsequently used to delineate between particular Paragorgia species. Note: "-“ represents an unknown morphological characteristic; reference based on Smithsonian Institute's catalogue of species

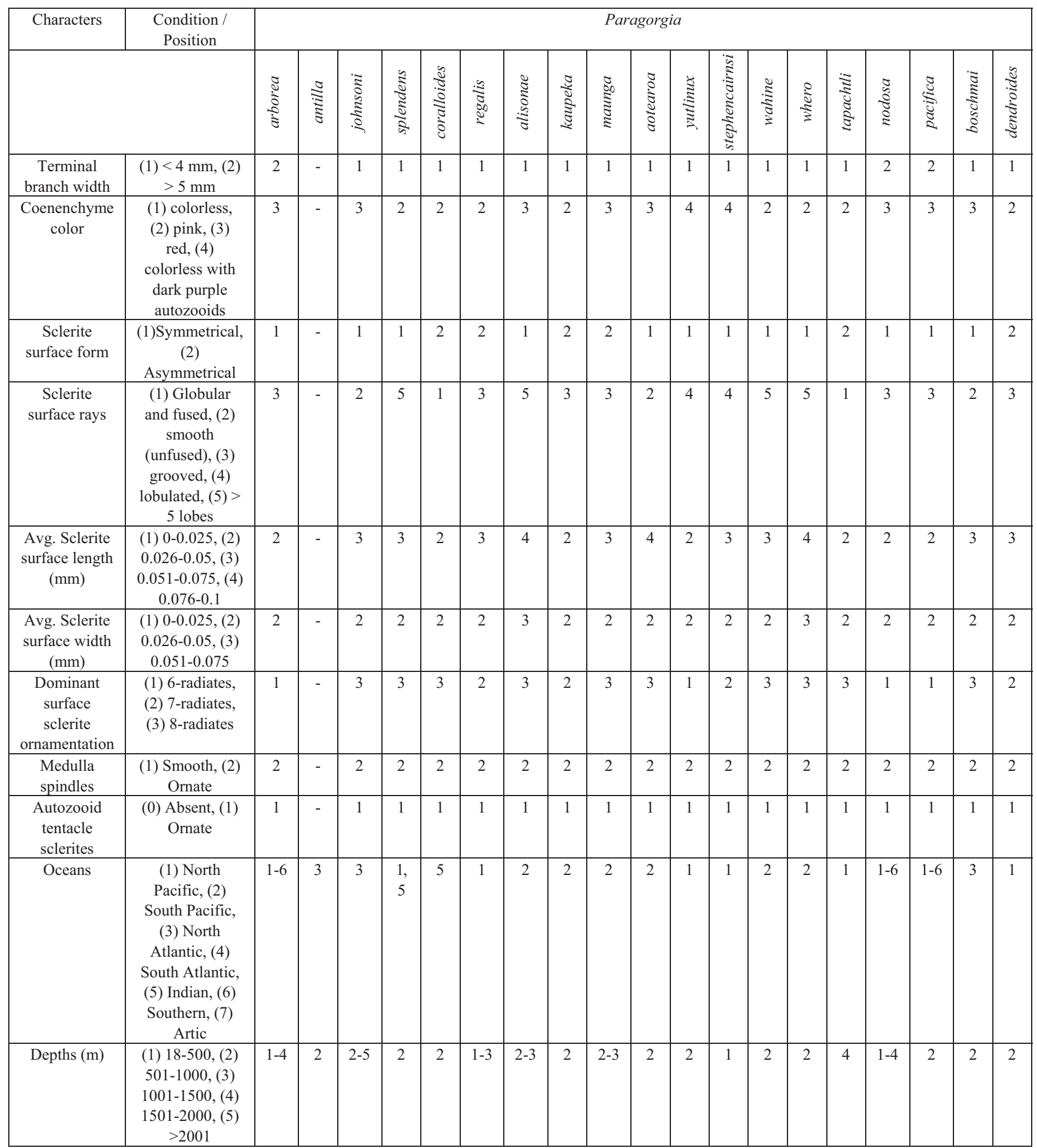


Table 2. Accession numbers of $18 \mathrm{~S}$ rDNA gene sequences of deep cold-water taxa used in this study begin with the prefix "HM437". All sequences consist of $>1650$ nucleotides. Accession numbers are related to National Centre for Biotechnology Information (NCBI) coding. Paragorgia sp.* represents a "control" gene from Berntson et al., (1999, 2001); Beroe cucumis (GenBank Accession \# D15068) represents an out-group used for tree formation. Deep cold-water samples are from Atlantic Canada unless otherwise mentioned. Symbols B = Bermuda; $\mathrm{CA}=$ Canadian Atlantic; $\mathrm{CP}=$ Canadian Pacific; $\mathrm{G}=$ the Gully; $\mathrm{N}=$ Northeast Channel; $\mathrm{S}=$ Stone Fence (see Figure 1); "not. cat." = not catalogued. Numbers "1" = 186 to $250 \mathrm{~m}$, "2" = 262 to $472 \mathrm{~m}$, "3" = 509-630 m; letters "a, b, c" correspond to number of replicates at each depth

\begin{tabular}{|c|c|c|c|c|c|c|c|}
\hline $\begin{array}{c}\text { Accession } \\
\text { number }\end{array}$ & $\begin{array}{c}\text { Scientific } \\
\text { name }\end{array}$ & Strain & Origin & $\begin{array}{c}\text { Depth } \\
\text { range }(\mathrm{m})\end{array}$ & $\begin{array}{c}\text { Actual } \\
\text { Depth (m) }\end{array}$ & $\begin{array}{l}\text { Nucleotides } \\
\text { (bp) }\end{array}$ & Citation \\
\hline & Phylum Ctenophora & & & & & & \\
\hline \multirow[t]{4}{*}{ D15068 } & Beroe cucumis & not. cat. & not. cat. & not. cat. & not. cat. & 1676 & $\begin{array}{l}\text { Kobayashi et } \\
\text { al., * }\end{array}$ \\
\hline & Phylum Cnidaira & & & & & & \\
\hline & Class Hydrozoa & & & & & & \\
\hline & $\begin{array}{l}\text { Family } \\
\text { Hormathiidae }\end{array}$ & & & & & & \\
\hline \multirow[t]{3}{*}{ AF052890 } & Hormathiidae gen. sp. & AD2294-2 & Fieberling Guyot & not. cat. & 640 & 1800 & $\begin{array}{l}\text { Berntson et al., } \\
1999\end{array}$ \\
\hline & Order Alcyonacea & & & & & & \\
\hline & Family Alcyoniidae & & & & & & \\
\hline \multirow[t]{2}{*}{ AY838564 } & Anthomastus sp. (CA) & SeqM-2 & G-3 & $>500$ & not. cat. & 1792 & $\begin{array}{l}\text { Strychar et al., } \\
2005\end{array}$ \\
\hline & Family Nidaliidae & & & & & & \\
\hline \multirow[t]{2}{*}{ AF052927 } & Siphonogorgia sp. & 58584 & $\begin{array}{c}\text { Augulpelu Island, } \\
\text { Palau }\end{array}$ & not. cat. & $110 \mathrm{ft}$ & 1823 & $\begin{array}{l}\text { Berntson et al., } \\
2001\end{array}$ \\
\hline & $\begin{array}{c}\text { Suborder } \\
\text { Scleraxonia }\end{array}$ & & & & & & \\
\hline \multirow[t]{2}{*}{ AF052922 } & Anthothela nuttingi & CR106-1 & $\begin{array}{c}\text { Cross Seamount, } \\
\text { Hawaii }\end{array}$ & not. cat. & 1,010 & 1822 & $\begin{array}{l}\text { Berntson et al., } \\
2001\end{array}$ \\
\hline & $\begin{array}{l}\text { Family } \\
\text { Paragorgiidae }\end{array}$ & & & & & & \\
\hline AF052917 & Paragorgia sp.* & AD2301-1 & Fieberling Guyot & not. cat. & 490 & 1799 & $\begin{array}{l}\text { Berntson et al., } \\
2001\end{array}$ \\
\hline AY838559 & P. arborea $(\mathrm{CP})$ & Seq7-2 & Can-Pacific & $18-250$ & 265 & 1800 & $\begin{array}{l}\text { Strychar et al., } \\
2005\end{array}$ \\
\hline AY838562 & P. johnsoni (B) & Seq9-2 & Bahamas-1 & not. cat. & not. cat. & 1734 & $\begin{array}{l}\text { Strychar et al., } \\
2005\end{array}$ \\
\hline \multirow[t]{24}{*}{ AY838563 } & P. arborea $(\mathrm{CA})$ & SeqJ-2 & Can-Atlantic & $18-250$ & $18-250$ & 1802 & $\begin{array}{l}\text { Strychar et al., } \\
2005\end{array}$ \\
\hline & P. arborea & Par-12 & Bahamas-2 & not. cat. & not. cat. & 1798 & HM437199 \\
\hline & P. arborea & G-1 & S-1a & $186-250$ & 186 & 1738 & HM437174 \\
\hline & P. arborea & F-1 & S-1b & $186-250$ & 186 & 1743 & HM437175 \\
\hline & P. arborea & Par-1 & S-1c & $186-250$ & 186 & 1798 & HM437200 \\
\hline & P. arborea & Seq J-2 & S-2a & $262-472$ & 262 & 1688 & HM437201 \\
\hline & P. arborea & $\mathrm{I}-1$ & S-2b & $262-472$ & 321 & 1696 & HM437176 \\
\hline & P. arborea & $\mathrm{K}-2$ & S-2c & $262-472$ & 332 & 1736 & HM437177 \\
\hline & P. arborea & E-1 & S-3a & $509-630$ & 630 & 1688 & HM437178 \\
\hline & P. arborea & E-2 & $\mathrm{S}-3 \mathrm{~b}$ & $509-630$ & 588 & 1688 & HM437179 \\
\hline & P. arborea & $\mathrm{F}-2$ & $\mathrm{~S}-3 \mathrm{c}$ & $509-630$ & 588 & 1688 & HM437180 \\
\hline & P. arborea & $\mathrm{J}-1$ & G-1a & $186-250$ & 236 & 1692 & HM437181 \\
\hline & P. arborea & $\mathrm{H}-2$ & G-1b & $186-250$ & 236 & 1688 & HM437182 \\
\hline & P. arborea & $\mathrm{J}-2$ & G-1c & $186-250$ & 236 & 1694 & HM437183 \\
\hline & P. arborea & $\mathrm{I}-2$ & G-2a & $262-472$ & 472 & 1740 & HM437184 \\
\hline & P. arborea & $\mathrm{I}-3$ & G-2b & $262-472$ & 472 & 1689 & HM437185 \\
\hline & P. arborea & D-1 & G-2c & $262-472$ & 472 & 1690 & HM437173 \\
\hline & P. arborea & K-1 & G-3a & $509-630$ & 556 & 1700 & HM437186 \\
\hline & P. arborea & G-2 & G-3b & $509-630$ & 556 & 1686 & HM437187 \\
\hline & P. arborea & $\mathrm{H}-1$ & G-3c & $509-630$ & 556 & 1711 & HM437188 \\
\hline & P. arborea & Par-9 & $\mathrm{N}-1 \mathrm{a}$ & $186-250$ & 246 & 1798 & HM437189 \\
\hline & P. arborea & Par-11 & $\mathrm{N}-1 \mathrm{~b}$ & $186-250$ & 249 & 1798 & HM437190 \\
\hline & P. arborea & Par-2 & $\mathrm{N}-1 \mathrm{c}$ & $186-250$ & 250 & 1798 & HM437191 \\
\hline & P. arborea & Par-5 & $\mathrm{N}-2 \mathrm{a}$ & $262-472$ & 262 & 1798 & HM437192 \\
\hline
\end{tabular}




\begin{tabular}{|c|c|c|c|c|c|c|c|}
\hline & P. arborea & Par-6 & $\mathrm{N}-2 \mathrm{~b}$ & $262-472$ & 380 & 1798 & HM437193 \\
\hline & P. arborea & Par-10 & $\mathrm{N}-2 \mathrm{c}$ & $262-472$ & 411 & 1798 & HM437194 \\
\hline & P. arborea & Par-7 & $\mathrm{N}-2 \mathrm{~d}$ & $262-472$ & 456 & 1802 & HM437195 \\
\hline & P. arborea & Par-8 & $\mathrm{N}-3 \mathrm{a}$ & $509-630$ & 573 & 1798 & HM437196 \\
\hline & P. arborea & Par-3 & $\mathrm{N}-3 \mathrm{~b}$ & $509-630$ & 509 & 1798 & \\
\hline & & & & & & & $\begin{array}{ll} & \text { HM43719 } \\
7 & \end{array}$ \\
\hline & P. arborea & Par-4 & $\mathrm{N}-3 \mathrm{c}$ & $509-630$ & 542 & 1798 & HM437198 \\
\hline & $\begin{array}{l}\text { Family } \\
\text { Acanthogorgiidae }\end{array}$ & & & & & & \\
\hline AF052925 & $\begin{array}{l}\text { Calcigorgia } \\
\text { spiculifera }\end{array}$ & not. cat. & $\begin{array}{c}\text { Aleutian Islands, } \\
\text { Alaska }\end{array}$ & not. cat. & 431 & 1852 & $\begin{array}{l}\text { Berntson et al., } \\
2001\end{array}$ \\
\hline \multirow[t]{2}{*}{ AF052907 } & Acanthogorgia sp. & BI104-3 & $\begin{array}{c}\text { Bishop Seamount, } \\
\text { Hawaii }\end{array}$ & not. cat. & 1,295 & 1852 & $\begin{array}{l}\text { Berntson et al., } \\
1999\end{array}$ \\
\hline & Family Plexauriidae & & & & & & \\
\hline \multirow[t]{2}{*}{ AF052920 } & Paramuricea sp. & CR105-5 & $\begin{array}{c}\text { Cross Seamount, } \\
\text { Hawaii }\end{array}$ & not. cat. & 1145 & 1850 & $\begin{array}{l}\text { Berntson et al., } \\
2001\end{array}$ \\
\hline & Family Gorgoniidae & & & & & & \\
\hline AF052928 & Leptogorgia chilensis & not. cat. & $\begin{array}{c}\text { Santa Catalina Island, } \\
\text { California }\end{array}$ & not. cat. & 15 & 1823 & $\begin{array}{l}\text { Berntson et al., } \\
2001\end{array}$ \\
\hline \multirow[t]{2}{*}{ AJ133545 } & Acalycigorgia inermis & & & not. cat. & not. cat. & 1822 & Won et al., 2001 \\
\hline & $\begin{array}{l}\text { Family } \\
\text { Chrysogorgiidae }\end{array}$ & & & & & & \\
\hline AF052913 & $\begin{array}{l}\text { Chrysogorgia } \\
\text { chryseis }\end{array}$ & CR106-2 & $\begin{array}{c}\text { Cross Seamount, } \\
\text { Hawaii }\end{array}$ & not. cat. & 1,010 & 1811 & $\begin{array}{l}\text { Berntson et al., } \\
2001\end{array}$ \\
\hline
\end{tabular}

Table 3. Primers used to amplify and sequence $18 \mathrm{~S}$ rDNA from deep-water fauna. Primers are listed as: "A1-A5" representing forward primers and "B1-B5" representing reverse primers. Primers A1 and B1 were located according to the DNA sequence of the 18S rRNA gene from Paragorgia sp. (AF052917; Berntson et al., 2001); the remaining primers were from Strychar et al. (2005). Primer locations (PL) are given with respect to the sequence given in AF052917

\begin{tabular}{|c|l|l|l|l|l|}
\hline \multicolumn{7}{|c|}{ Deep-water Fauna 18S rDNA PCR and Sequencing Primers } \\
\hline \multicolumn{2}{|c|}{$\begin{array}{c}\text { Forward Compliment } \\
\text { (A1 - A5) }\end{array}$} & \multicolumn{1}{|c|}{ PL } & & $\begin{array}{c}\text { Reverse Compliment } \\
\text { (B1 - B5) }\end{array}$ & PL \\
\hline A1 & AACCTGGTTGATCCTGCCAGT & $2-22$ & B1 & TGATCCTTCTGCAGGTTCACCTAC & $1776-1799$ \\
\hline A2 & TGAAACTGCGAATGGCTCAT & $81-100$ & B2 & TTTGACCAACTTCTCGGCGG & $1715-1734$ \\
\hline A3 & TAATTCCAGCTCCAATAGCG & $582-601$ & B3 & CTGGACCTGGTAAGGTTTCC & $1202-1221$ \\
\hline A4 & ACGATGCCGACTAGGGATG & $1031-1050$ & B4 & CCTGCTTTGAACACTCTAATTTCT & $759-782$ \\
\hline A5 & CGTCGTGATGGGAATAGATC & $1531-1550$ & B5 & GGGACTTTTCGCATGTATTAGC & $163-184$ \\
\hline
\end{tabular}




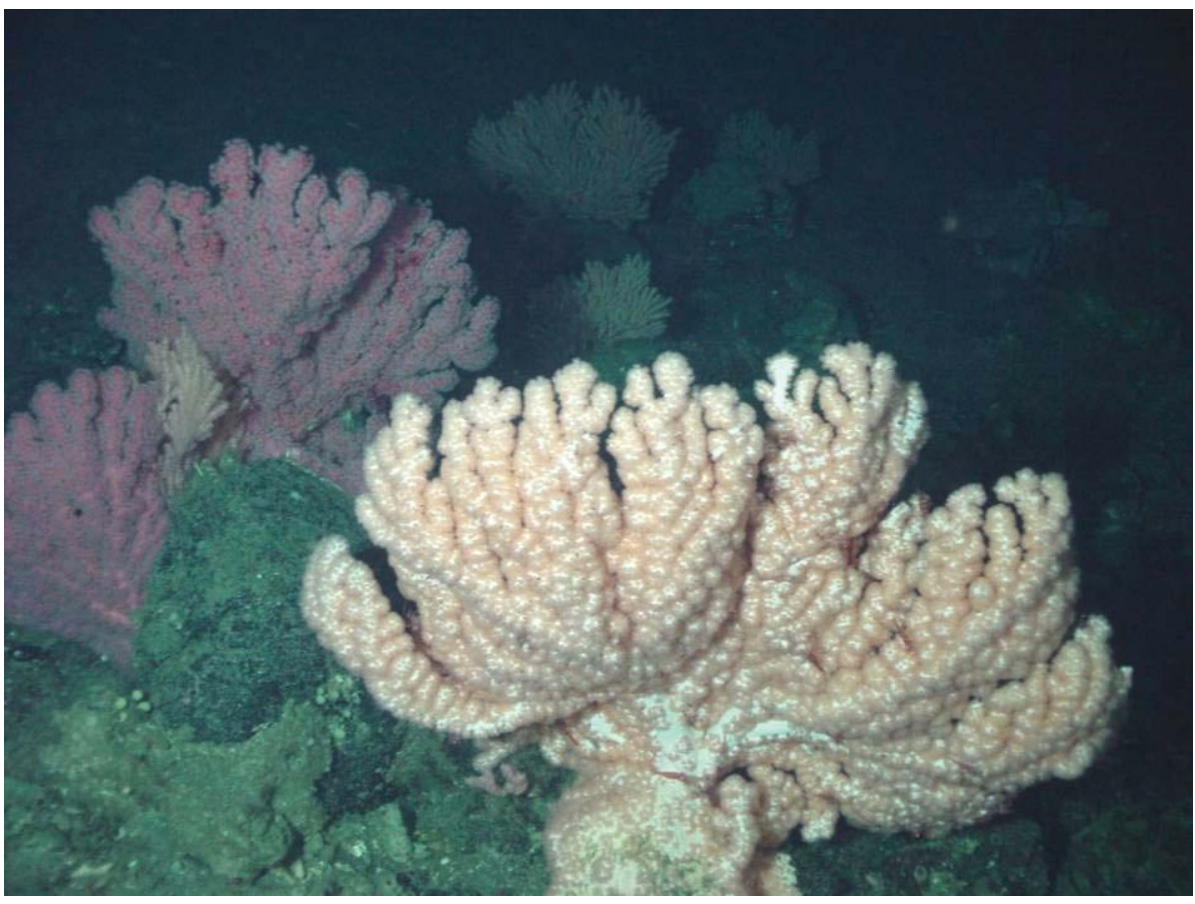

Figure 1. Paragorgia arborea photographed during the 2006 Discovery Cruise on CCGS Hudson from the ROPOS submersible at approximately $950 \mathrm{~m}$ depth in the Northeast Channel

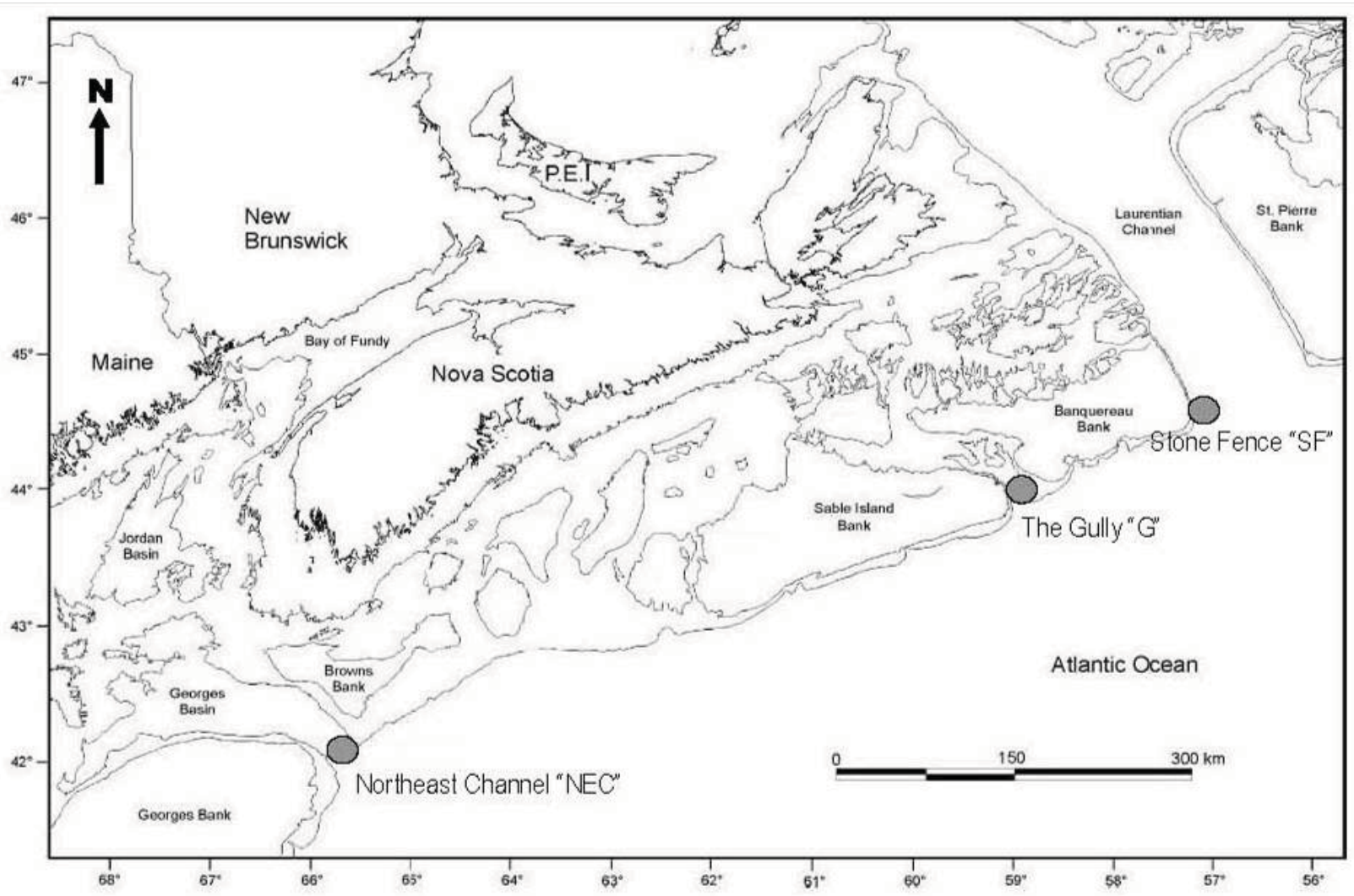

Figure 2. Map of Nova Scotia (Canada) showing sample locations of deep cold-water corals (CWCs) 


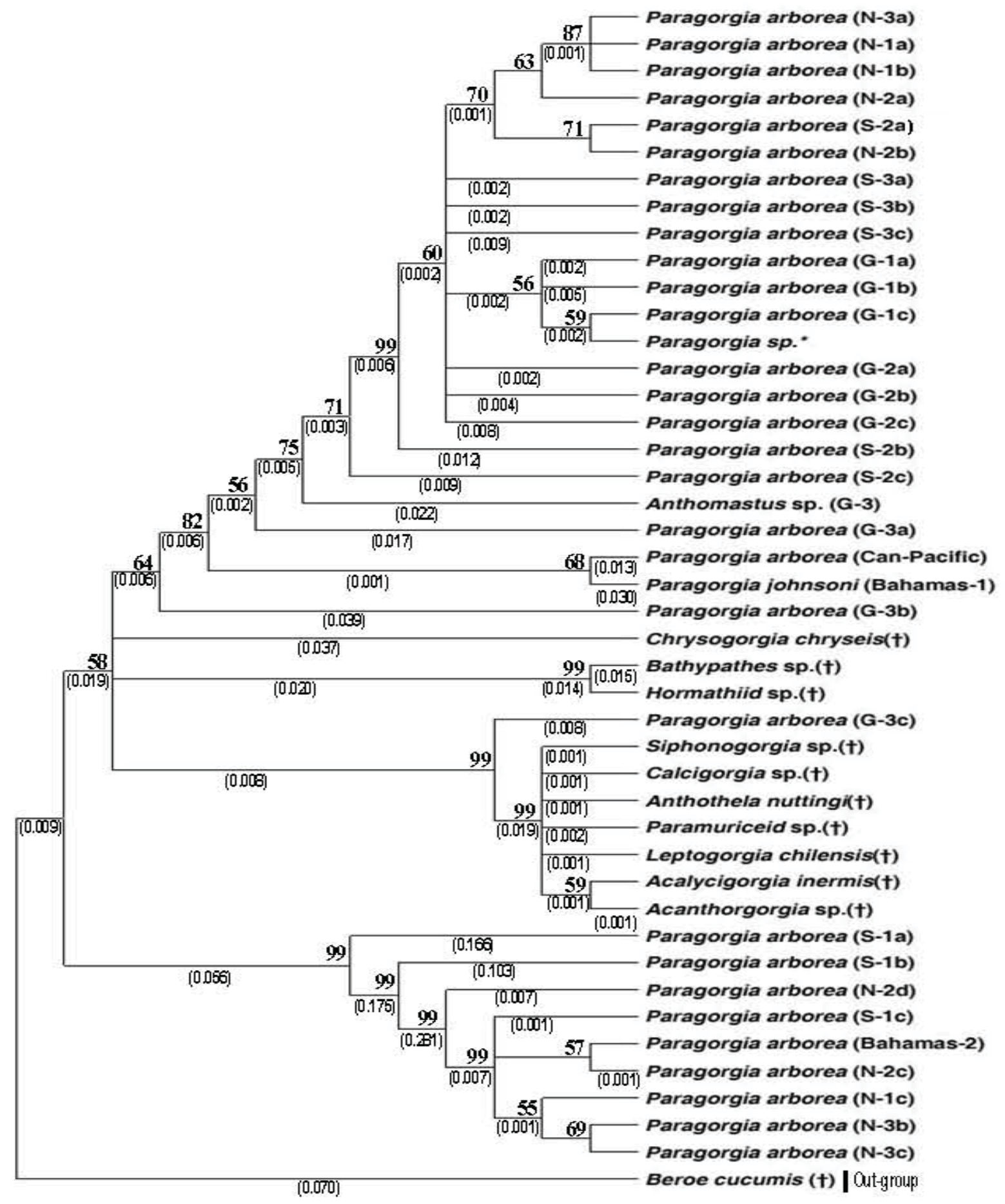

Figure 3. Phylogenetic tree from minimum-evolution (ME) analysis. Bootstrap analysis ( $\mathrm{n}=1,000,000$ replicates) provided an estimate of support for internal nodes ranging from 50 to $100 \%$ (on top of corresponding branch; values $<50 \%$ are not shown). The number in brackets indicates substitutions per nucleotide position (values $<0.001$ are not shown). Paragorgia sp.* represents "control" gene from Berntson et al., (1999, 2001); out-group used for tree construction was Beroe cucumis (D15068; Berntson et al., 2001). Symbols: Bahamas-1 = sample collected from Bermuda; Bahamas-2 = specific site of location unknown, but region is Bahamas; $\mathrm{CA}=\mathrm{Canadian}$ Atlantic; $\mathrm{CP}=$ Canadian Pacific; $\mathrm{G}=$ the Gully; $\mathrm{N}=$ Northeast Channel; $\mathrm{S}=$ Stone Fence. Numbers " 1 " $=186-250 \mathrm{~m}$, " $2 "=262-472 \mathrm{~m}, " 3 "=509-630 \mathrm{~m}$; letters "a, b, c" correspond to number of replicates at each depth 


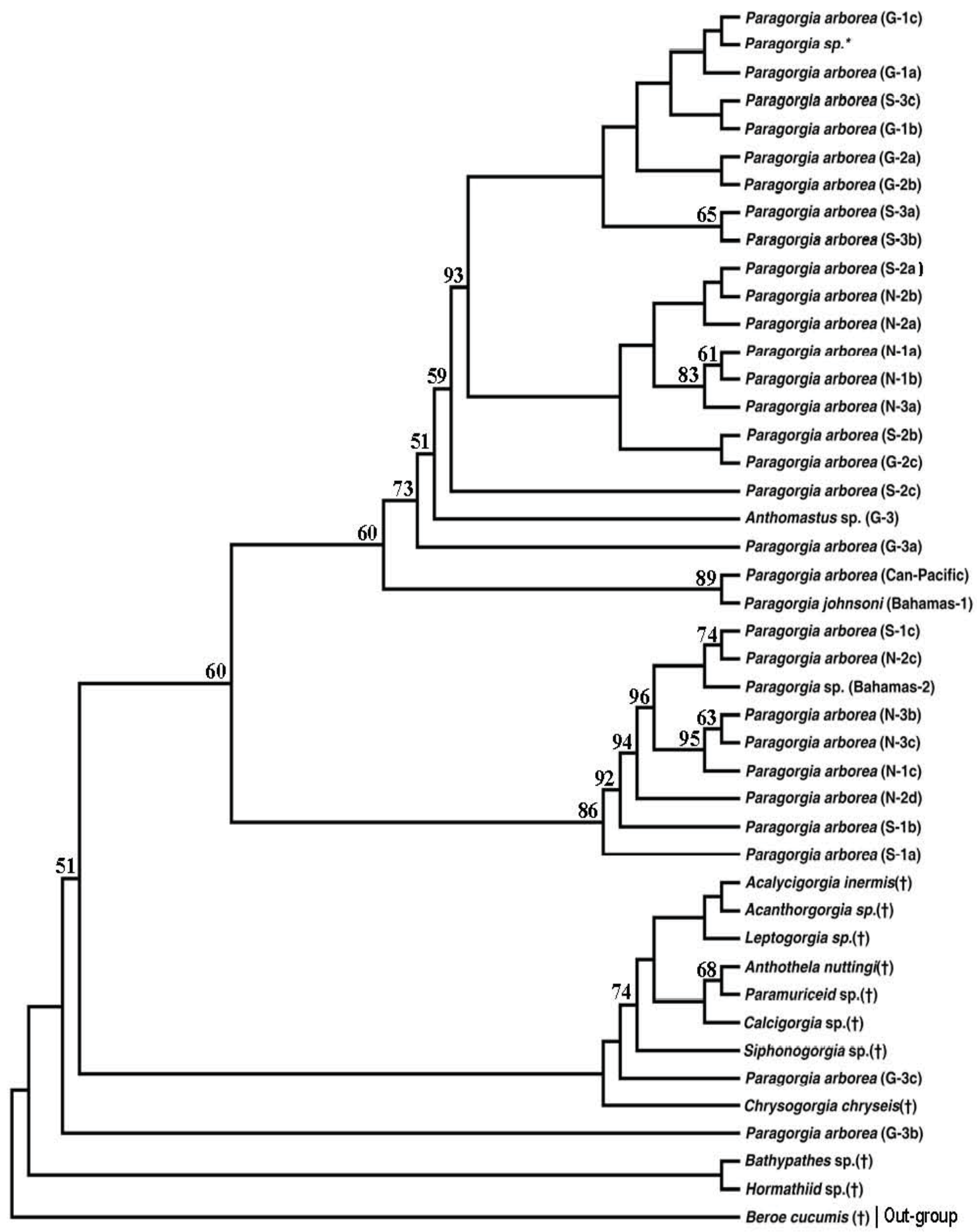

Figure 4. Phylogenetic tree from maximum likelihood (ML) quartet-puzzling analysis using PAUP (v. 4.010b; Swoford 2002). Bootstrap analysis $(n=1,000,000$ puzzling steps) provided an estimate of support for internal nodes ranging from 50 to $100 \%$. Note that branch lengths are arbitrary and only the pattern is important.

Paragorgia sp.* represents "control” gene from Berntson et al., (1999, 2001); out-group used for tree construction was Beroe cucumis (D15068; Berntson et al., 2001). Symbols: Bahamas-1 = sample collected from Bermuda; Bahamas-2 = specific site of location unknown, but region is Bahamas; $\mathrm{CA}=$ Canadian Atlantic; $\mathrm{CP}=$ Canadian Pacific; $\mathrm{G}=$ the Gully; $\mathrm{N}=$ Northeast Channel; $\mathrm{S}=$ Stone Fence. Numbers " 1 " = 186-250 m, "2" = 262-472 m, " 3 " = 509-630 m; letters "a, b, c" correspond to number of replicates at each depth 


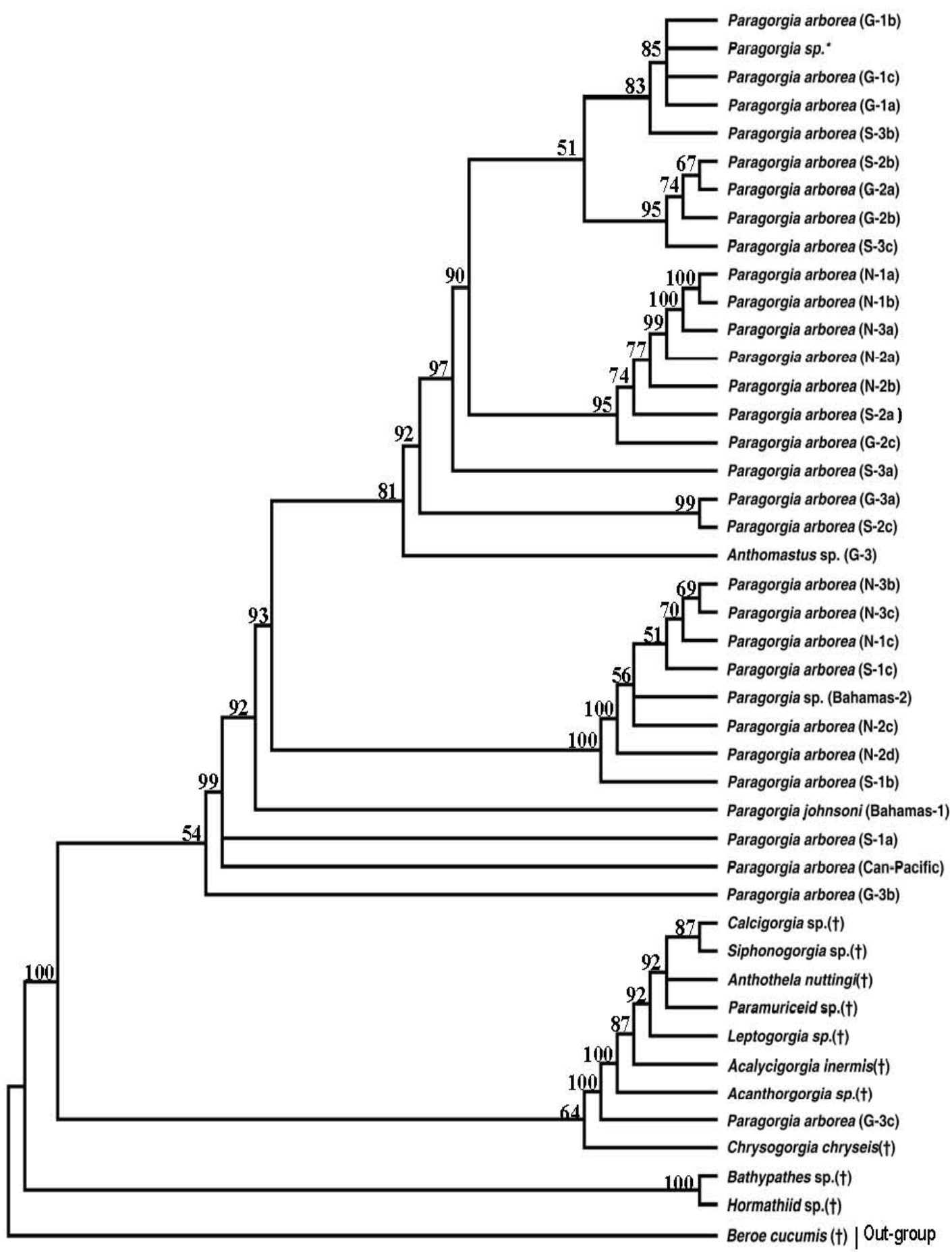

Figure 5. Phylogenetic tree from bayesian-likelihood (BL) analysis using the gamma function, 4-by-4 model, sampling 1,000,000 generations, with Markov chains sampled every 100 iterations. Above node support is the $50 \%$-majority-rule consensus from the sampled trees. Values $<50 \%$ are not displayed. Note that branch lengths are arbitrary and only the pattern is important. Paragorgia sp.* represents "control" gene from Berntson et al., (1999, 2001); outgroup used for tree construction was Beroe cucumis (D15068; Berntson et al., 2001). Symbols: Bahamas- 1 = sample collected from Bermuda; Bahamas- 2 = specific site of location unknown, but region is Bahamas; $\mathrm{CA}=$ Canadian Atlantic; $\mathrm{CP}=$ Canadian Pacific; $\mathrm{G}=$ the Gully; $\mathrm{N}=$ Northeast Channel; $\mathrm{S}=$ Stone Fence. Numbers $" 1 "=186-250 \mathrm{~m}, " 2 "=262-472 \mathrm{~m}, " 3 "=509-630 \mathrm{~m}$; letters "a, b, c" correspond to number of replicates at each depth 


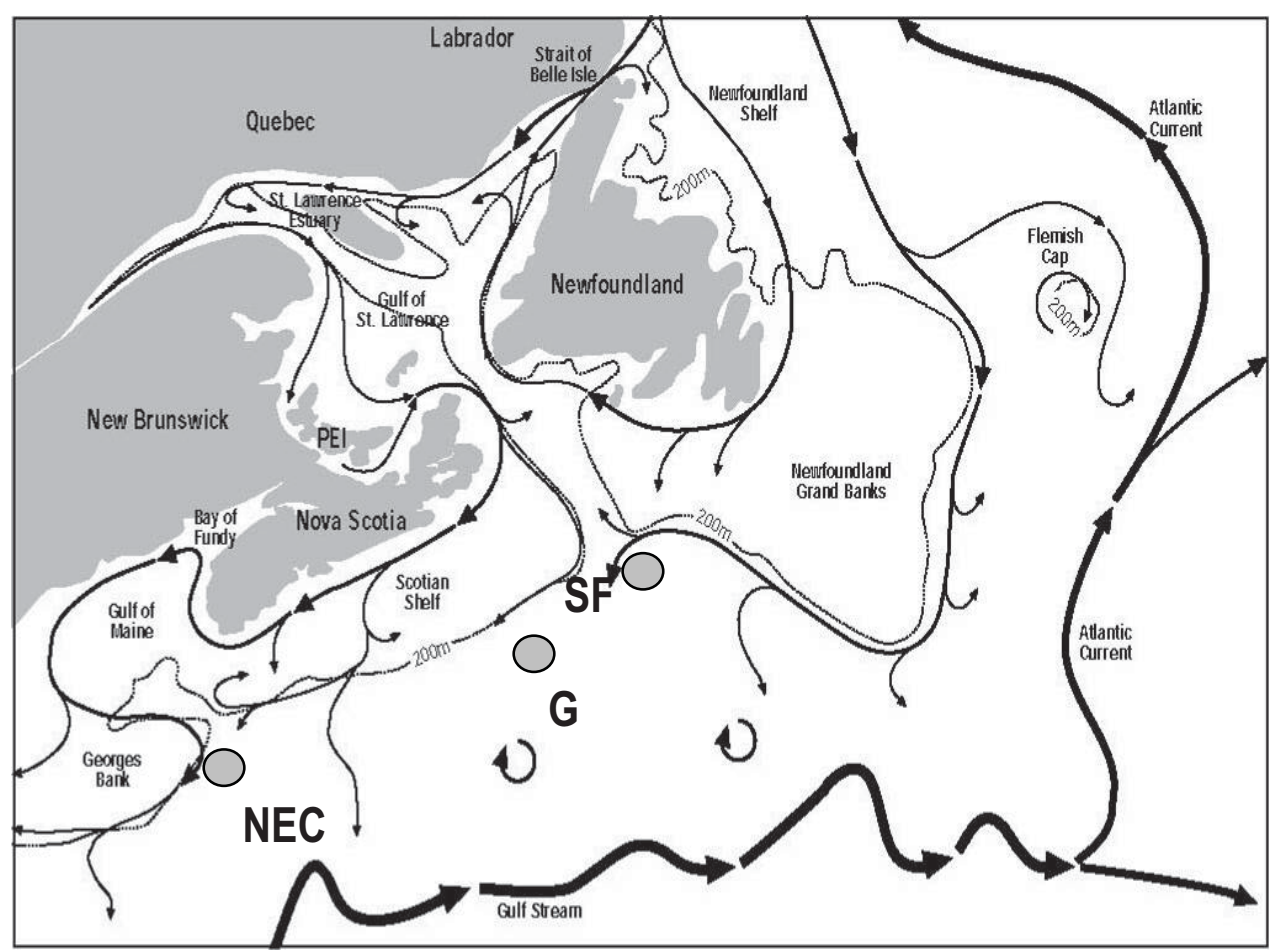

Figure 6. Scotian Shelf ocean circulation patterns along the eastern coast of Nova Scotia, Canada (adapted from Davis et al., 1998). Symbols $\mathrm{G}=$ the Gully; $\mathrm{NEC}=$ Northeast Channel; $\mathrm{SF}=$ Stone Fence 